Int. Arch. Allergy 1958;12:I-XIX

\title{
Contents, Vol. 12, 1958
}

International Archives

of

Allergy and Applied Immunology

Incorporating the Transactions of the Collegium Internationale Allergologicuî and the

Proceedings of the International Association of Asthmology and of

National Allergy Societies

A. v. ALBERTINI, Zurich D. BOVET, Roma

C. J. C. BRITTON, London

T. BROMAN, Göteborg

L. BUSINCO, Roma A. CERLETTI, Basel H. A. E. v. DISHOECK, Leiden J. DUGHAINE, Bruxelles G. ESTRADA DE LA RIVA, Havana

F. J. FARRERONS-CO,

Barcelona

D. G. R. FINDEISEN, Dresden

P. FORMIJNE, Amsterdam

R. A. GOOD, Minneapolis, Minn. F. GRÖER, Krakow W. GRONEMEYER,

Bad Lippspringe A. GRUMBAGH, Zurich M. J. GUTMANN, Jerusalem

CONTRIBUTING EDITORS:

F. HAHN, Düsseldorf

B. HALPERN, Paris

K. HANSEN, Bühlerhöhe E. A. KABAT, New York

G. LÖFSTRÖM, Uppsala

W. LUTZ, Basel

J. R. MARRACK, Cambridge

R. MEIER, Basel

J. A. MORETTI, Montevideo

T. OGATA, Tokyo

A. OLIVEIRA-LIMA

Rio de Janeiro D. ORDMAN, Johannesburg W. PAGEL, London M. M. PESHKIN, New York J. R. PRAKKEN, Amsterdam W. J. QUARLES van UFFORD,

Utrecht
A. R. RICH, Baltimore, Md.
B. M. B. RILEY, Sidney
C. RIMINGTON, London
M. ROCHA E SILVA, Sao Paulo
B. ROSE, Montreal
G. RUIZ MORENO, Buenos Aires
J. RUNNSTRÖM, Stockholm 
P. SANGIORGI, Milano

B. SCHICK, New York

H. SCHMIDT, Freiburg/Br.

L. SCHWARTZ, Washington, D.C.

H. SELYE, Montreal

U. SERAFINI, Firenze

A. STOLL, Basel

A. TISELIUS, Uppsala

G. L. WALDBOTT, Detroit, Mich.

\title{
EDITORS-IN-CHIEF:
}

\author{
R.R.A. Coombs \\ D. Harley \\ P. Kallós \\ W. Kaufman \\ W. Löffler \\ Cambridge \\ London \\ Helsingborg \\ Bridgeport, Conn.
}

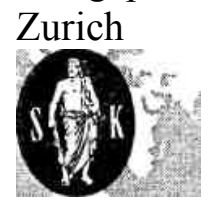

1958

Vol. 12

BASEL (Schweiz) S. KARGER NEW YORK

Contents - Inhaltsverzeichnis - Sommaire

Preface to Béla Schick Anniversary Number Ill

Béla Schick Curriculum Vitae

$\mathrm{V}$

Bibliography of Scientific Papers by Dr. Béla Schick

Homage to Béla Schick. By William Bennet Bean

Andrews, J. M. (Bethesda, Md.):

Allergy-Immunology Studies

17

Björklund, B.; Lundblad, G. and Björklund, V. (Stockholm):

Antigenicity of Pooled Human Malignant and Normal Tissues by CytoImmunological Technique: II. Nature of Tumor Antigen

241

Björklund, V.: vide Björklund, B.

Campbell, D. H. and Garvey, J. S. (Pasadena, Calif.):

The Fate of Labeled Foreign Antigens in the Livers of Normal and Immunized Rabbits 70

Cerletti, A.: vide Doepfner, W. 
Crowle, A. J. (Denver, Colo.):

A Simplified Modification of the Triangular Double-Diffusion Agar

Precipitin Test

215

De Oliveira, H. L. (Ribeirão Preto, Säo Paulo):

Analysis of Rat Kidney and Lung Extracts by Gel Diffusion Against

Anti-Rat-Kidney Serum 356

Doepfner, W. and Cerletti, A. (Basel, Switzerland):

Comparison of Lysergic Acid Derivatives and Antihistamines as Inhibitors

of the Edema Provoked in the Rat's Paw by Serotonin 89

Egdahl, R. H. (Minneapolis, Minn.):

Immunological Maturation and Defects in Immunological Capacity 305

Fries, J. H. (Manhaset, N. Y.):

An Evaluation of Allergenic and Non-AUergenic Incitants of Gastro

intestinal Symptoms 106

Garvey, J. S.: vide Campbell, D. H.

Gottlieb, P. M. (Philadelphia, Pa.):

Bronchial Asthma in Childhood

Hansen, K. (Bühlerhöhe, Baden):

Über soziale Probleme beim Asthma bronchiale

152

Hiramoto, R.: vide Pressman, D.

Karelitz, S. (New Hyde Park, L. I., N. Y.):

My Personal Recollections of Dr. Béla Schick

1

Lecomte, J. (Liège): Reactions anaphylactiques "in vitro" des artères pulmonaires du lapin 339

Liebow, A. A. (New Haven, Conn.):

Diphtheria and the Schick Test in the Tropics

42

Lundblad, G.: vide Björklund, B.

Marrack, J. R. (Cambridge, England):

What is Diphtheria Toxin? 21

Maxwell, I. (Melbourne):

Bronchial Asthma in Australia , $\quad 137$

McCombs, R. P. (Boston, Mass.):

The Clinical Differentiation of "Allergic" Vasculitis from Periarteritis

Nodosa $\quad 98$

Misirlija, A.: vide Stern, P.

Ordman, D. (Johannesburg):

The "Climate Group" of Respiratory Allergy Patients

Olivier, H.-R. (Paris):

Sensibilité du poumon asthmatique à l'acétylcholine 262

Pagel, W. and Treip, C. S. (Barnet, Herts):

Notes on the Histological Criteria of Hypersensitivity

Pappenheimer, A. M., Jr. (New York, N. Y.):

The Schick Test, 1913-1958 35

Peshkin, M. M. (New York N. Y.):

Béla Schick as I know him

Philipson, L. (Uppsala):

Non-Diphtheritic Acute Subglottic Laryngitis (Croup) in Children. 
A Family Study

322

Pressman, D.; Yagi, Y. and Hiramoto, R. (Buffalo, N. Y.):

A Comparison of Fluorescein and I131 as Labels for Determining the

“in vivo" Localization of Anti-Tissue Antibodies 125

Selye, H. (Montreal):

Prevention by $\mathrm{MgCl} 2$ and $\mathrm{KC} 1$ of the Vascular Hypersensitivity Induced

by Pretreatment with Dihydrotachysterol (DHT) 145

Sherman, W. B. (New York, N. Y.):

Serum Sickness - $1957 \quad 59$

Speer, F. (Kansas City, Kansas):

The Allergic Tension-Fatigue Syndrome in Children

Stern, P. and Misirlija, A. (Sarajevo):

Die Bedeutung des Hauthistamins für den Haarwuchs bei Ratten und

Meerschweinchen 334

Stollerman, G. H. (Chicago, Ill.):

A Scarlatinal "Nachkrankheit" of Schick: Rheumatic Fever, 50 Years

Later 287

Treip, C. S.: vide Pagel, W.

Wachholz, P.: vide Werner, $\mathrm{M}$.

Waldbott, G. L. (Detroit, Mich.):

Contact Dermatitis in Children

273

Allergic Reactions from Fluorides 347

Werner, M. und Wachholz, P. (Pinneberg, Holstein):

Klinische und tierexperimentelle Untersuchungen zur Frage der serum-

allergischen in-vitro-LeukocytoIyse 223

Yagi, Y.: vide Pressman, D.

Proceedings - Gesellschaftsberichte - Sociétés

British Association of Allergists 361

Société Francaise d'Allergie $\quad 367$

News Items - Nachrichten - Nouvelles 375

Alle Rechte, insbeso $\pi$ dere das der Übersetzung in fremde Sprachen, vorbehalten

Ohne ausdrückliche Genehmígung des Verlages ist es auch nicht gestattet, dieses Buch oder

Teíle

daraus auf photomechaníschem Wege (Photokopie, Mikrokopie) zu vervielfältigen

(C)

Copyright 1958 by S. Karger AG., Basel.

Printed in Switzerland by Buchdruckerei Aargauer Tagblatt, Aarau.

Cliches: Aberegg-Steiner \& Cie. AG., Bern, und Steiner \& Cie. AG., Basel.

Béla Schíck

Anniversary Number in Honor of His 80th Birthday

edited by

WILLIAM KAUFMAN 


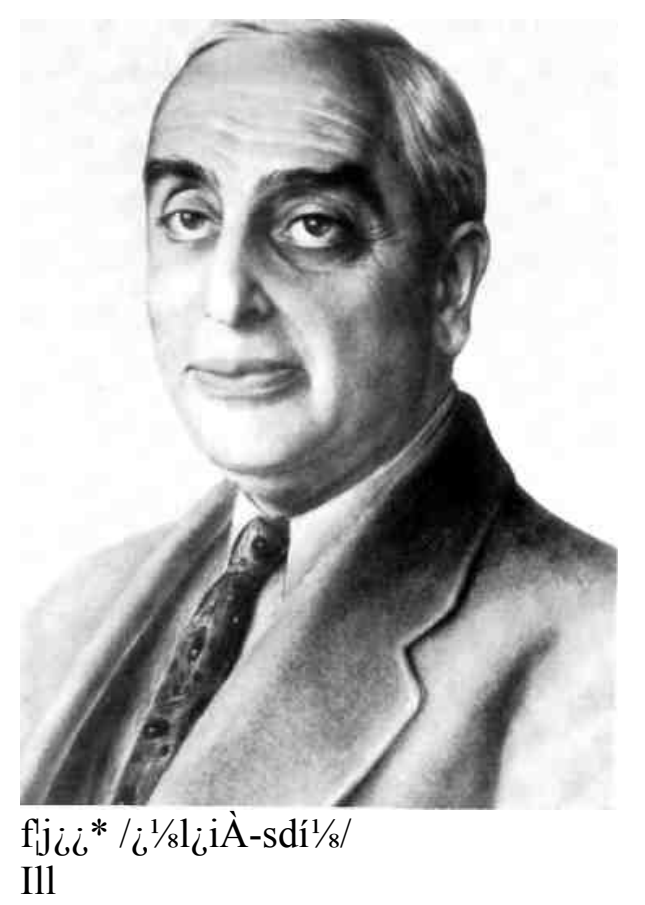

Preface

This volume is affectionately dedicated to Dr. Béla Schick as a Festschrift on the occasion of his eightieth birthday. Few physicians have worked so hard for so long and have accomplished so much for their fellow human beings as has Dr. Schick. Not only has he contributed over the years to the health and welfare of children directly under his care, but through his basic contributions to medicine there are today millions of people all over the world who owe their health and even their lives to him; and future generations will undoubtedly benefit also from the works of this great man.

I first met Dr. Schick almost eighteen years ago when I was a medical resident at the Mount Sinai Hospital in New York City, and looked after a few of his older pediatric patients on the Private Pavilion. My first impression was that he was a friendly but shy and retiring man who wore a natural mantle of modesty. Gentle, he was always the objective observer of the sick child and his illness, having the keen, inquisitive mind of the research medical scientist. But at the same time he was sensitive, perceptive and conscientious, and to him there was nothing routine about the care of his young patients. Each child always received individualized attention. Long before it became fashionable to talk about the psychosomatic approach of treating the whole patient, Dr. Schick, in addition to giving each pediatric patient the medical therapy he needed, also gave him tender loving care which comforted the sick, frightened child and set him at ease in the hospital environment. Sick children looked forward to his next visit as they would to that of a kind friend, an older playmate, a protector against pain and suffering. Only a person who genuinely loves children can win their trust, affection and respect as Dr. Schick always has. In the best tradition of medicine, he has always been dedicated to his medical work, and to the service of humanity. Therefore, it does not come as a surprise to those who know him that today, at the age of 80, when most men have long been retired from their labors, Dr. Schick is happily continuing with the medical work he loves, now doing important research in the field of infant prematurity, and taking care of patients in consultation and private practice.

IV 
The basic contributions of Béla Schick over the years to medicine are too well known to need recounting here, and these include works on serum sickness, diphtheria, scarlet fever, and infant and child nutrition. Not only are these works of importance in themselves, but also they have acted as an enormous stimulus to medical thought, imagination and endeavor in many fields of clinical and basic medical research.

When my fellow editors asked me to plan and edit the Béla Schick Festschrift, I decided that this volume should contain articles by leading medical scientists and physicians on topics in allergy and immunology in which they were most interested, and especially qualified to write about. The enthusiastic response that I had to my letters of invitation is but one measure of the universal respect and admiration which the scientific world has for Béla Schick. The papers in this volume represent only a small sampling of the world of allergy and immunology as it exists today. As in all samplings, not every possible subject has been included, but many important aspects of allergy and immunology are covered.

In order to avoid the usual delays in publication of a book such as the Béla Schick Festschrift, our publisher, Dr. Heinz Karger, graciously suggested that the papers for the Festschrift first be issued in sequential numbers of the International Archives of Allergy and Applied Immunology, to be called the Béla Schick Festschrift, Parts 1, 2, 3, 4, etc. This method of procedure allows for prompt publication of the many important scientific contributions that comprise this volume. Then, when all these papers have appeared in the Archives, they will be collected and issued in book form as the Béla Schick Festschrift.

Thanks are due to Dr. Karger, who took a deep personal interest in making the Béla Schick Festschrift possible, and to the editors of the Archives, especially Dr. Paul Kallós, who offered encouragement and excellent advice. I am indebted to Dr. Kallós for final editing of the papers written in German and French. I am also grateful for the splendid cooperation of the distinguished medical scientists and clinicians who contributed papers for this volume. Finally, I wish to thank my wife, Charlotte S. Kaufman, who cheerfully helped me with this undertaking, as she has with so many others.

W.K.

IX

Nahrungsbedarf der Frau im letzten Drittel der Schwangerschaft. Z. Kinderheilk. 23: 26 (1919). Ernährungsstudien beim Neugeborenen, 3. Mitteil. Z. Kinderheilk. 27: 57 (1920). Freiluftspital f. tuberkulöse Kinder. Z. Kinderschutz 12: 53 (1920). Das Menstruationsgift (Menotoxin). Wien. klin. Wschr. 33: 395 (1920). Icterus Neonatorum, eine Folge des Abbaues mütterlichen Blutes. Z. Kinderheilk. 27:

231 (1920). Das Pirquet'sche System und seine Gegner. Z. Kinderheilk. 28: 62 (1921). Über konzentrierte Ernährung und deren Indikation besonders im Säuglingsalter.

I. Mitt. Z. Kinderheilk. 30: 121 (1921). With E. Helmreich. Über konzentrierte Ernährung. 2. Mitt. Einfluß wechselnder Konzentr. auf Körpergew.

u. Harnm. Z. Kinderheilk. 30: 147 (1921). With E. Helmreich. Ernährungsstudien beim Neugeborenen. 4. Mitt. Z. Kinderheilk. 30: 363 (1921).

With E. Helmreich. Über eine Verdauungsstörung jenseits des Säuglingsalters, 1. Mitt. Z. Kinderheilk. 30:

223 (1921). WithÆ. Wagner. Neue Wege der Di-Prophylaxe. Klin. Wschr. 1: 25 (1922). With Kassowitz. Diphtheriediagnose. Wien. med. Wschr. 72: 1484 (1922). Über die Ursache des negativen Ausfalles der Di-Hautreaktion bei maligner D. Klin. 
Wschr. 7: 1691 (1922). Verdauungsstörung jenseits des Säuglingsalters. 2. Mitt. Z. Kinderheilk. 35: 263

(1923). With R. Wagner. Intrakutane Reaktionen. Handb. d. Biologischen Arbeitsmeth. v. Abderhalden. Abt.

XIII/2, p. 507 (1923). With von Groer and Kassowitz. Acetonstudien beim Neugeborenen. Z.

Kinderheilk. 37: 263 (1924). With R. Wagner. Verteilung der Gelbfärbung der Haut beim Icterus Neonatorum. Z. Kinderheilk. 38:

513 (1924). Reorganisation of Nutrition Work to Save Food Waste in Childrens' Departments. Mod. Hosp. 23: 117 (1924). The Development of the Intracutaneous Di-toxintest. N. Y. State J. Med. 24: 756

(1924). Die Pulszahlen des Foetus, des Säuglings und des Kleinkindes. Z. Kinderheilk. 38:

216 (1924). Observation of the Nutritional Effect of Subcutaneous Oil Injections. Proc. Soc. exp. Biol., N. Y., 21: 445 (1924). With M. Fries et al. Concentrated Feeding. Arch. Pediat. 42: 397 (1925). Health Conservation Class. Hosp. Soc. Serv. 12: 81 (1925). Lowered Basal Metabolism in Postinfectious Stages and in Diseases Characterized by

Slow Pulse Rate. Amer. J. Dis. Child. 30: 291 (1925). With Ph.Cohn. The Predisposing Factor in Diphtheria. N. Y. State med. J. 114: 197 (1925). The Basal Metabolism after Pneumonia. Amer.

J. Dis. Child. 31: 228 (1926). With

A. Topper. Die Diphtherie-Intrakutan-Reaktion. Wien. med. Wschr. 77: 755 (1927).

Tuberculosis in Childhood. Med. Clin. Nth Amer. 12: 561 (1928). Effect of Tonsillectomy and of Adenoidectomy on Di-immunity. Amer. J. Dis. Child.

38: 929 (1929). With A. Topper. Di-Schutzimpfung in den Vereinigten Staaten v. Nordamerika.

Ergebn. soz. Hyg. 1:

146 (1929). Kindertuberkulose in Amerika. Handb. d. Kindertuberkulose. Engel u. Pirquet, Band 2 ,

p. 1537 (Thieme, Leipzig 1930). Gefahrenzone bei der aktiven Immunisierung gegen Diphtherie. Wien. med. Wschr. 80:

(1930). Behandlung der Serumkrankheit. Kinderärztl. Praxis 1: 12 (1930).

$\mathrm{V}$

Béla Schick

Curriculum Vitae

Born: July 16, 1877 Boglar, Hungary.

Educated: Staats-Gymnasium, Graz, Austria, 1894.

Karl Franzens University, Graz, Austria, M. D. 1900. Volunteer Intern, Medical, Psychiatric and Children's Clinic,

University of Graz, 1900-1902. University of Vienna, 1902-1923:

Children's Clinic: Sekundärarzt 1903, Assistent 1907, Privat-dozent 1912.

Extraordinary Professor of Children's Diseases, 1918-1923. Attending Pediatrician, Mount Sinai Hospital, New York, 1923-

1942. Consulting Physician, Mount Sinai Hospital, New York, 1942. Director, Pediatric

Department, Seaview Hospital, New York, 1928-1942. Consulting Pediatrician, Willard Parker Hospital, 1928-1957. Consulting

Pediatrician, New York Infirmary for Women and

Children. Clinical Professor, Diseases of Children, Postgraduate Medical Faculty, Columbia University, 1938-1942. Lecturer, Columbia University, 1943-1949. Director, Pediatric Service, 
Beth El Hospital, Brooklyn, N. Y. Visiting Professor of Pediatrics, Albert Einstein College of Medicine

of Yeshiva University, New York. Chief Pediatric Consultant, Children's Asthma Research

Institute

and Hospital, Denver, Colorado. Chief Pediatric Consultant, Jewish National Home for

Asthmatic

Children, Denver, Colorado. Contributing Editor, International Archives of Allergy and Applied Immunology.

VI

Honorary Member:

Albert Einstein College of Medicine (Founders' Group),

American College of Allergists,

American-Hungarian Medical Association of New York,

Bronx Pediatric Society,

Collegium Internationale Allergologicum,

Deutsche Gesellschaft für Kinderheilkunde,

Finnish Pediatric Society,

Gesellschaft der Ärzte, Wien,

Harvey Society, New York,

International Association of Allergists (Founders' Group),

Medical Circle, New York,

Mississippi Valley Medical Society,

Pediatric Section of Kings County, Brooklyn,

Sociedad Boliviana de Pediatria,

Société Française d'Allergie,

Southwestern California Pediatric Society,

Virchow Society, New York,

Wiener Gesellschaft für Kinderheilkunde.

Member:

Academy of Pediatrics (Founders' Group),

Academy of Science,

American Association of Immunologists,

American Pediatric Society,

Association for the Study of Allergy,

National Institute for Social Sciences,

New York Academy of Medicine,

Society for Experimental Biology and Medicine,

Society of Pediatric Research.

Awards:

Harvey Lecturer, 1923, Cutter Lecturer, 1923, Gold Medal, Academy of Medicine, 1938,

Addingham Gold Medal, Leeds, 1938,

Gold Medal, Midwest Forum of Allergy, Indianapolis, 1941, Justice Brandeis Gold Medal, 1950,

Howland Medal and Award, 1954,

Semmelweis Medal, American-Hungarian Medical Association, 1955. Doctor of Humane

Letters, Yeshiva University, 1955, Mordecai Ben David Award, 1957, Parents' Magazine Medal, 1957 , 
Annual National Award, Mennen Baby Foundation, 1957,

Award for Service to Mankind, American Jewish Congress (Business and Professional Associates), 1957. City of New York, Certificate for Distinguished Service, 1958.

VII

Bibliography of Scientific Papers by Dr. Béla Schick

Hypertrophia Cerebri. Jb. Kinderheilk. 57: 423 (1903).

Variabilität der Diphtheriebacillen. Wien. klín. Wschr. 16: 993 (1903). With H. Ersettig.

Zur Theorie der Inkubationszcit. Wien. klin. Wschr. 16: 758 (1903). With v. Pirquet.

Zur Theorie der Vakzination. Verh. Ges. Kinderheilk. (1903). With v. Pirquet.

Urotropin und Scharlachnephritis. Wien. klin. Wschr. 17: 967 (1904).

Spezifische Agglutination von Streptokokken aus Scharlachanginen, usw. Wien. klin.

Wschr. 18: 3 (1905). With E. Rosíval. Weitere Erfolge der Serumbehandlung des Scharlachs.

Dtsch. med. Wschr. 31: 2092

(1905). Die Diagnostische Tuberkulinreaktion im Kindesalter. Jb. Kinderheilk. 61: 811 (1905).

Serumkrankheit. Monographie (Deuticke, Wien 1905). With v. Pirquet. Zur Frage des

Aggressins. Wien. klin. W1/8chr. 18: 431 (1905). With v. Pirquet. Postscarlatinöse

Lymphadenitis. Jb. Kinderheilk. 62: 661 (1906). Nachkrankheiten, Infektiosität und Therapie des

Scharlachs. Handb. Kinderheilk.

Pfaundler-Schlossman. I. Aufl. (Vogel, Leipzig 1906). Serumkrankheit. Handb. Kinderheilk.

Pfaundler-Schlossman. I. Aufl. (Vogel, Leipzig

1906). With v. Pirquet. Überempfindlichkeit und beschleunigte Reaktion. Munch, med. Wschr. 103: 66 (1906).

With v. Pirquet. Nachkrankheiten des Scharlachs. Jb. Kinderheilk. 65: 132 (1907). Therapie des

Scharlachs. Berl. klin. Wschr. 44: 709 (1907). Herzstörungen bei Scharlach. Verh. dtsch. Ges.

Kinderheilk. (1907). Chlorstoffwechsel und Körpergewícht im Scharlach. Z. klin. Med. 66: 352

(1908).

With 0. Gruener. Über ein den Koplikschen Flecken analoges Frühsymptom der Masern an der

Caruncu-

la. Mitt. Ges. inn. Med. Kinderheilk., Wien 7: 64 (1908). Kutanreaktion bei Impfung mit

Diphtherietoxin. Munch, med. Wschr. 55: 504 (1908). Diphtheriekutanreaktion. Verh. dtsch.

Ges. Kinderheilk. 25: 330 (1908). Die physiologische Nagellinie des Säuglings. Jb. Kinderheilk.

67: 137 (1908). Sulla Cutíreazione Difterica. Biochim. Ter. sper. 1: 1 (1909). Intrakutane

Wertbestimmung des Diphtherieantitoxins. Handb. Technik und Methodik

der Imm. Forsch., Kraus-L·evaditi (1909). Diphtheriekutanreaktion beim Meerschweinchen. Z.

ImmunForsch. 4: 550 (1909).

With E. Novotny. Homologe und heterologe passive Anaphylaxie. Z. ImmunForsch. 3: 671

(1909).

With E. Novotny. Über ein durch Trauma auslösbares postscarlatinöses Exanthem (Erythema post-

scarlatinosum). Jb. Kinderheilk. 71: 123 (1910). Gehalt des Serums diphtherie- und

masernkrankcr Kinder an Schutzkörper gg. D-Toxin.

Jb. Kinderheilk. 72: 460 (1910). With M. Karasawa.

VIII

Untersuch ü. d. Gehalt menschlicher Sera an Schutzkörper gg. Di-Toxin. Jb. Kinder-

heilk. 72: 144 (1910). With M. Karasawa. Quantitative Bestimmung des Resorptionsverlaufes subcutan eingef. Di-serums. Z. 
Kinderheilk. /: 62 (1910). With M. Karasawa. Vakzineinfektion des Kaninchens m. intrakutaner Injektion von Kuhpockenlymphe.

Z. ImmunForsch. 5: 688 (1910). With E. Novotny. Scharlach. Handb. Kinderheilk. Pfaundler-

Schlossman, 2. Aufl. (Vogel, Leipzig 1910). Scheinbares Aufflammen abg.

Tuberkulinreaktionen während der Eruption von

Masern. Mschr. Kinderheilk. 5: 137 (1910). Exspiratorisches Keuchen als Symptom der

Lungendrüsentbc. im 1. Lebensjahre.

Wien. klin. Wschr. 23: 135 (1910). Röteln. Ergebn. inn. Med. Kinderheilk. 5: 280 (1910).

Diphtherie-Immunität. Verh. dtsch. Ges. Kinderheilk. 28: 212 (1911). With M. Karasawa.

Passive Übertragung der intrakutanen Tubcrkulinreaktion beim Meerschweinchen.

Z. ImmunForsch. 9: 275 (1911). With E. Novotny. Versuche mit intrakutaner Injektion von

Diphtherietoxin. Dtsch. Ges. Kinderheilk.,

Münster 1912. With Fr. Magyar. Diphtheriekutanreaktion beim Meerschweinchen bei

wiederholter Injektion. Zbl. Bakt.

Orig. 66: 121 (1912). With So. Wertbestimmung des Schutzkörpergehaltes menschl. Serums

durch intrakutane Injektion

beim Menschen. Z. Kinderheilk. 5: 349 (1912). Behandlung des Scharlachs mit Moserserum.

Ther. Mh. 26: 258 (1912). Intrakutanreaktion des Menschen auf Di-Toxininjektion als Ausdruck des Schutzkörpergehaltes seines Serums. Z. Kinderheilk. 5: 232 (1912). With Michiels. Zwei Fälle von familiärer spin. Muskelatrophie. Wien. med. Wschr. 62: 1186 (1912). Scharlach. Monographic Nothnagels Handbuch (Holder, Wien 1912). With Th. Escherich. Malignes Granulom mit recurrierendem Fieber. Z. Kinderheilk. 5: 493, 1913. Diphtheriehautreaktion als Vorprobe d. prophylakt. Diphtherieseruminjektion. Munch.

med. Wschr. 60: 2608 (1913). Spezifische Therapie der Diphtherie, Referat Mikrobiologentag. Zbl. Bakt. Beiheft 57:

16 (1913). Experimentelle Diphtherieserumtherapie. Verh. dtsch. Ges. Kinderheilk. 30: 168 (1914).

With Busacchi und Kassowitz. Experimentelle Diphtherieserumtherapie. Z. exp. Med. 4: 83 (1914). With Busacchi

u. Kassowitz-Verhalten d. Menschen geg. ausgeglichene Toxin-Antitoxin Misch. Z. exp. Med. 4: 305 (1914). With Kassowitz. Fortschritte in der Therapie der Diphtherie. Wien. med. Wschr. 64:

1965 (1914). Zur Frage der physiol. Körpergewichtsabnahme des Neugeborenen. Z. Kinderheilk. 13:

257 (1915). Der Kampf gegen die Tuberkulose des Kindesalters. Oest. Sanitätswes. 27: 15 (1915). Ein Fall von Beschneidungstbc. Wien. klin. Wschr. 30: 1629 (1917). Ernährungsstudien beim Neugeborenen, I. Mitteilung. Z. Kinderheilk. 17: 1 (1918). Tuberkulose im Kindesalter. Klinik Prognose u. Behandlung. Oest. Sanitätswes. 30:

334 (1918). Das Pirquet'sche System der Ernährung (auch als Broschüre in 2 Auflagen). Ergebn. inn. Med. Kinderheilk. 16: 384 (1919). Ernährungsstudien beim Neugeborenen, 2. Mitt. Z. Kinderheilk. 22: 195 (1919). Nahrungsbedarf der stillenden Frau. Wien. med. Wschr. 69: 1557 (1919). Nahrungsbedarf der stillenden Frau. Z. Kinderheilk. 21: 284 (1919).

$\mathrm{X}$

Parenteral BCG Vaccine. Amer. J. Dis. Child. 43: 273-283 (1932). With W. H. Park and C. Kereszturi. Clinical Observation in Parenteral BCG Vaccination. Acta paediat. 2: 400 (1932). 
With W. H. Park and C. Kereszturi. Zur Behandlung der Toxicose im Säuglingsaltcr. Z. Kinderheilk. 53: 466 (1932). Treatment of Alimentary Toxicosis. J. amer. med. Ass. .9.9: 366368 (1932). Trans.

Sect. Pediat. pp. 66-73 (1932). Writh S. Karelitz. Pathogenesis of Diphtheria. Emanuel Libman Anniversary, vol.3, p. 1047 (International

Press, New York, 1932). Aktive Immunisierung gegen Diphtheric. Referat Deutsche Ges. f. Kinderheilkunde

Dresden. Mschr. Kinderheilk. 51: 454 (1932). Mascrnschutzimpfung mit Erwachsenenserum reaktiviert durch Exposition zu Masern.

Wien. med. Wschr. 82: 1395 (1932). With S. Karelitz. Tubercle Bacilli in the Stomach Content of Children with Positive Tuberculin Test.

J. amer. med. Ass. 98: 1879 (1932). With C. Kereszturi, L. Mishulow et al. Acid-fast Bacilli in the Stomach Lavage and Faeces of Tuberculous Children. J. amer.

med. Ass. 100: 1481 (1933). With C. Kereszturi, D. Hauptman et al. Chemical Allergy and

Nirvanol Sickness. Amer. J. Dis. Child. 45: 1216 (1933). With

S. Peck and H. Sobotka. Metabolismo Basal en los Niños. Paidoterapia, June (1933). With A.

Topper. Allergy. Roundtable Conference. J. Pediat. 4: 75 (1934).

Child Care Today, Textbook (Greenberg, New York 1934). With W. Rosenson. Abnormal

Nutritional States in Children. Med. Clin. Nth Amer. 17: 1219 (1934).

With A. Topper. Diphtheric Handb. d. Kinderhcilk. Pfaundler-Schlossman. 4. Aufl., Band 2, p. $1-90$

(1934). Allergy. Roundtable Conference II. J. Pediat. 5: 698 (1934). Epidemiologic Factors in Measles Prophylaxis. J. amer. med. Ass. 104: 991-994 (1935).

With S. Karelitz. Tuberculosis. Roundtable Conference. J. Pediat. 7: 855 (1935). Congenital

Malaria. Mt. Sinai Hosp. Bull. 2: 147 (1935). With M. Stein. Follow-Up Study of 629

Tuberculous Children. Scaview Hosp. Bull. 1: 314 (1936).

With C. Kereszturi and H. Rosenberg. Die Infektionsgefahr in Kinderspitälern. Wien. med.

WГschr. 86: 803-804 (1936). Essential Xanthomatosis; Treatment with Cholesterol-Free Diet in

2 Cases. Amer. J.

Dis. Child. 51: 1372-1384 (1936). With W. M. Sperry. Tuberculosis in Childhood. Med. Clin.

Nth Amer. 20: 719-735 (1936). Allergy and Immunity. Radiol. Rev. 59: 1-7 (1937).

Pirquet Cubicles for Infants. J. amer. med. Ass. 108: 1684-1688 (1937). With S. Karelitz.

Tuberculosis in Childhood. Radiol. Rev. 59: 177-182 (1937). Zur Behandlung des akuten

Gelenk-Rheumatismus im Kindesalter. Schweiz. med.

Wschr. 67: 987-988 (1937). Typical Form of Splenomegaly in Childhood. Phlebosclerosis of Portal Circulation.

J. Mt. Sinai Hosp. 4: 221-224 (1937). With M. Freiind. Influence of Vitamin C on Diphtheria

Toxin. Amer. J. Dis. Child. 55: 12-26 (1938).

With J. Pakter. Skin Reaction with Diphtheria Toxin on Human Beings as Test Preceding Prophylactic Injection of Diphtheria Serum. J. Mt. Sinai Hosp. 5: 26-28 (1938). Common Forms of Childhood Tuberculosis. Med. Clin. Nth Amer. 23: 645-660 (1939). Child Care Today

(Greenberg, New York 1940). With W. Rosenson, new edition. Thoracoplasty in Children. J. Mt. Sinai Hosp. 7: 486-489 (1941). With B. Singer. Prevention of Dental Caries by Massive Doses of Vitamin D. Amer. J. Dis. Child. 62:

1183-1187 (1941). With R. H. Brodsky and H. Vollmer.

XI 
Diphtheria. In: Litchfield and Dumbo: Therapeutics in Infancy and Childhood (Davis, Philadelphia 1942). Problem of Allergy in Rheumatic Disease. J. Mt. Sinai Hosp. 8: 991-994 (1942). Icterus Index of Cord Blood; Genesis of Icterus Neonatorum. Amer. J. Dis. Child. 64: 655-660 (1942). With S. B. Weiner and M. Reiner. Tea Prepared from Needles of Pine Trees Against Scurvy. Science 98: 241-242 (1943). Case of Neurofibromatosis in Child 5-3/4 Years of Age. J. Mt. Sinai Hosp. 10: 399-

401 (1943). Edema with Hypoproteinemia due to Congenital Defect in Protein Formation (Case Report), J. Pediat. 27: 241-245 (1945). With J. W. Greenbaum. Tratamiento de las Enfermedades Infeccionsas; Agentes Terapéuticos y Biologicos para

Combatirlas; informe del Comité de la "American Academy of Pediatrics". Arch. argent. Pediat. 24: 228, 317 (1945). With J. A. Toomey. Allergy and Immunity. J. Mt. Sinai Hosp. 14: 595 (1947). The Newborn Service in New York. Oest. Z. Kinderheilk. 3: 147 (1949). Diaplacental Infection of the Fetus with the Virus of German Measles Despite Immunity of the Mother. Analogous Observations in Smallpox. Acta pediat. 38: 563-570 (1949). Placental Transmission of Mumps and Streptococcus M. G. Antibodies. Proc. Soc. exp. Bid., N. Y. 78: 126-128 (1951). With A. Florman and H. Scalattar. Serum Sickness (English Translation). (Williams and Wilkins, Baltimore 1951). With

v. Pirquet. Physiologic and Pathologic Allergy. J. Mt. Sinai Hosp. 19: 240-242 (1952). Five Articles. Brennemann's Practice of Pediatrics, 1948-1953:

Diphtheria. 2: Chapter 4.

Serum Sickness. 2: Chapter 2.

Immunity, Allergy and Anaphylaxis. 1: Chapter 4.

Bronchial Asthma. 2: Chapter 57.

Hayfever. 2: Chapter 58. With M. Peshkin.

Ehrlich and Problems of Immunity. Ann. N. Y. Acad. Sci. 59: 182-189 (1954).

The Use of Gamma Globulin in Infection Refractory to Antibiotics. J. Mt. Sinai Hosp.

21: 148-161 (1954). With J.R.Harris. Das übertragene Neugeborene. Wien. klin. Wschr. 67: 658659 (1955).

With S. Gall and J. R. Harris. Acceptance of John Howland Medal and Award of American Pediatric Society. Amer.

J. Dis. Child. 89: 246-254 (1955). Physiologic and Pathologic Allergy. Ann. Allergy $\backslash 4:$ 247-253 (1956). The Founding of the Science of Allergy. Ann. Allergy 14: 343-348 (1956). Views in Perspective. Amer. Rev. Tuberc. 74: 290-296 (1956). Erythema Neonatorum Allergicum J. Dis. Child. 92: 27-33 (1956). With J. R. Harris. Problemas Pediatricas. Libros Homenageal Prof. Rafael Ramos, pp. 11-17, Barcelona,

(1957). Pediatrics in Vienna at the Beginning of the Century. J. Pediat. 50: 114-124 (1957). Serum Sickness and Serum Sickness-like Reactions. N. Y. State J. Med. 57: 11101112 (1957). Problems of Pediatrics. Ann. paediat. Fenn. 3: 241-248 (1957). Experiences in Pediatrics During the Last Fifty Years. Med. Clin. Nth Amer. 41: 1049-1060 (1957).

\section{XIII}

Homage to Béla Schick

By William Bennett Bean

State University of Iowa, University Hospitals, Department of Internal Medicine, Iowa City, Iowa. 
The welcome occasion of a festschrift for Dr. Béla Schick brought to me the unexpected honor of joining his happy colleagues and admirers in paying tribute to a man whose greatness has never hardened a warm heart and a gentle love of his fellow creatures, especially those who are children. Some persons cannot endure the bright light of fame. They lose compassion and humility in false pride from a wrong estimate of their own uniqueness. Not so Béla Schick, who has retained the simple virtues which are the marks of true greatness. In my portion of these dedicated papers, I have been asked to measure the man and his work against the receding milestone markers of history. For this task I have no special training, but the stimulating challenge and opportunity have given me the occasion to read and reread Schick's major papers and review his conspicuous achievements. My deficiencies for this task I trust are balanced by the warmth of my admiration.

Béla Schick, hurrying to get into the world, even if it meant a premature birth, was almost too speedy. Only the fact that his uncle was a physician and ready at hand made available the extra effort and care to save the infant who even then seemed to be impatient to get on with his work. It is fitting that much of Schick's present effort is directed to the study of prematurity.

Details of Béla Schick's youth, his student days, the wonderful unfolding of his career in close association with Pirquet as well as the details of his later life, his coming to America at the age of 46 where he might easily have coasted on his worldwide renown, his continual association with and contributions to pediatrics and general medicine - these events and much else are detailed for us by Antoni Gronowicz in his charming biography entitled "Béla Schick and the World of Children". A major point of his medical and scientific career is that the association with Pirquet was a true brotherhood of feeling and a mutual fulfilment of two brilliant minds, at once complementing and supplementing each other. This combination, brought together in the harness of discipline, resulted in discoveries which have developed into a whole new field of medicine. Probably neither member of this team knew just which one contributed what part of their developing ideas and observations. It was a true partnership.

Some physicians today may think of Schick's name as being merely the eponym of a wonderfully useful scratch test. A special form of immortality belongs to those whose names have become a permanent strand in the moving folkways of language. Few of us stop to think of boycott, macadam, pasteurize, bowdlerize as people or words derived XIV

from the names of people. But Schick is much more than a word, and if his scratch test has been entered on the formal scrolls of fame, his real virtue is etched deeper, graven on the monument reserved for those who have been fortunate and wise enough to add to man's stature by illuminating what was dark and showing us its significance. An interest in history is one expression of the gratefulness we all should feel towards that numerous band of workers, mostly lost among our ancestors, who have made possible our society and our life today. While a real feeling for history has dwindled before the casual apathy of our time, this festschrift indicates that hero worship is not dead if we can but find a worthy hero. And so we atone in some degree by expressing our admiration of a great man in simple terms of piety.

To those who work in lavish laboratories, who have their research supported by the largess of many and generous grants-in-aid, it is a chastening thought to realize how modest were the physical auspices under which Schick and Pirquet made their careful studies of patients which enabled them to describe the essential features of serum sickness, to discover allergy and help characterize the mechanisms of obscure diseases. In the realm of ideas they reached a high level 
of excellence without project, grant, or fancy apparatus, perhaps not even realizing what they were missing.

The accomplishments of Schick and Pirquet will stand as one of the rare germinal discoveries, a nodal point in medical and general history. Consider in how few ways disease may be produced in man. Probably fewer than ten. What we call disease is the response of an organism to some noxious force or process, within or without. The classes of provoking mechanisms are few infection or parasite, neoplasm, lack of specific elements in the diet, deformity of structure or metabolic fault as inborn error, injury from physical trauma, poisoning and not least allergic or hyper sensitivity reactions. It may be said that these last were born, not as premature infants, or infants at all, but fully developed from the fused intellect of Schick and Pirquet as Athene emerged, whole and beautiful, from the head of iלeus.

We who have grown up in medicine since allergy has been one of the cornerstones can hardly picture the situation just over fifty years ago when no such concept existed. It is easy enough to recognize features of a landscape when we have the maps and guidebooks. But how can we recapture the insights needed for the first perception of the significance of strange new or unfamiliar observations which are made as clinical science becomes a force in medicine. It reminds me of the changes which one recognizes when he revisits old familiar ground over new roads in a fast moving automobile. As an illustration, last summer our family drove in the Blue Ridge mountains where I had spent many summers as a growing boy. A whole day of hiking in those days took us no further than we could move now in five minutes. Before I quite had my bearings, we had passed the whole territory now contracted and made so easy for travel by fine roads and a nimble car. My tales of climbing over rocks and jungles of bush and briars shriveled as another example of the blown-up memories of the nostalgic older generation. Just so we see the new roads and splendid vehicle by which we travel over the old terrain, claimed from the pathless thickets of ignorance by the pioneer work of Be'la Schick. For in him we have a discoverer, one of the band of true medical pioneers,

$\mathrm{XV}$

who opened up to the broad highway of allergic and hyper sensitivity phenomena along which many important travels in medicine go continually.

The field of allergy has so many ramifications today that it is hard to realize it is a mere fifty years old. This lusty child, this brain child of Béla Schick and Pirquet is now well established in the family of medicine. Allergy now spreads outward into the macrocosm of medical ecology becoming part of the working fabric of psychosomatic medicine and medical sociology. Allergy also turns inward to the microcosm of cell, and gene, and enzyme systems. The science of allergy uses many new drugs to alleviate misery. Knowledge of allergic mechanisms is helping clarify our ideas about the patho-genesis of collagen diseases, rheumatic fever and nephritis. Puzzles still unsolved hide some of the mysteries of other diseases when elements of the body, becoming unduly sensitive, wage civil warfare against other tissues. This may ruin function or produce a ghastly kind of internal self cannibalizing of cells or tissues. To have recognized the principles upon which rest the medical discipline of allergy and hyper sensitivity is the crowning intellectual achievement of Béla Schick.

In our day of turbulent physical and emotional strain, neurotic preoccupation with self has dulled the appetite for hero worship. Rarely do we honor our great men until they are dead. Then we see their deeds and achievements in the generosity of afterthought. We unveil busts or portraits, endow lectureships and in other ways try to make amends for neglecting them during life. Fortunately this festschrift honors Béla Schick, very much alive and vital as a busy physician and 
teacher, with patients and students, continuing to share with others when he might well rest on his many and well deserved laurels. You may recall in "Ruddigore", one of Gilbert and Sullivan's most charming light operas, a gallery of awe-inspiring ancestors stepped out of their portraits to see to it that the younger generation did not fail to fulfill certain ancient family traditions. Never mind if the traditions were a little odd. But Béla Schick, a medical immortal by any standard, does not have to step down from any frame or any pedestal. He lives on, enjoying the recognition and praise of his peers, and living in and into immortality.

Some men never are mellow. Others mellow with age, if they can avoid spoiling in the process. I suspect that Béla Schick, and others like him, if there are any, has always been mellow, wise and kind. These qualities have ripened with the years of his long devotion to science and to his little patients, children everywhere, of all lands, all races, all colors in the great republic of medicine. Whitehead enjoined us to keep ever before us the picture and image of greatness, that we might thereby eschew the mean and petty. I know of no way to do this better than by recognizing and honoring greatness when we encounter it in such a man as Béla Schick. In praising him, his great discoveries, his charm, his warmth and his wisdom, we honor ourselves in doing homage to him and paying tribute to true greatness. Thus our medical generation, in singing his praises, congratulates him on his notable accomplishments and congratulates itself that he has lived on to share in person with his younger colleagues his own immortality.

Author's address: William B. Bean, M. D., State University of Iowa, University Hospitals, Department of Internal Medicine, Iowa City, Iowa (USA.). 